\title{
Persona as Personal Branding of Stand-Up Comedian in Indonesia
}

\author{
Lambok Hermanto Sihombing ${ }^{*}$, Anak Agung Sarwindah ${ }^{2}$, Glenity Marchella Siauw ${ }^{3}$, Steven \\ Chaniago ${ }^{4}$ \\ ${ }^{1234}$ Department of Communication, President University \\ Email: 1ambok@president.ac.id ${ }^{1 *}$
}

\begin{abstract}
Stand-Up comedy is the new trend of Pop Culture. In Indonesia, the Stand-Up comedy trend has spread to all places, from the very west of Indonesia Island to the Papua. This research analyses the pop culture of stand-up comedy and the new creative industry in Indonesia, focusing on Raditya Dika, Ernest Prakasa, Cak Lontong, Dodit Mulyanto and Uus. Furthermore, this research explores the persona of each comic that represents their style of performance. This essay also aims to find out the difference in persona of Indonesian Stand-Up Comedy artists and how they come up with the persona. For the data, we choose YouTube platform to be analyzed. We analyze the presented materials, video's thumbnails and the responses from the audiences. We use three theories during this research, which are Personal Branding Theory, Digital Media Theory, and Social Semiotics. The result shows that these comics are having different unique persona that sticks to themselves and make people recognize them.
\end{abstract}

Keywords: Persona, Stand-Up Comedy, YouTube

\begin{abstract}
Abstrak. Stand-Up komedi merupakan sebuah tren baru di dunia Budaya Populer. Di Indonesia, tren Stand-Up komedi telah menyebar ke seluruh wilayah, dari ujung barat sampai ke tanah Papua. Penelitian ini menganalisis budaya popular dari Stand-Up komedi dan industry kreatif baru di Indonesia yang berfokus pada beberapa komika seperti Raditya Dika, Ernest Prakasa, Cak Lontong, Dodit Mulyanto, dan Uus. Lebih jauh penelitian ini mendalami tentang persona dari setiap komika yang merepresentasikan gaya mereka di panggung. Artikel ini bertujuan untuk mencari perbedaan persona di pada setiap artis Stand-Up komedi dan bagaimana mereka muncul dengan personanya masing-masing. Data kami ambil dari platform YouTube untuk lebih lanjut di analisis. Kami menganalisa materi presentasi, cuplikan video, dan respon dari penonton. Artikel ini menggunakan tiga teori yaitu Personal Branding, Digital Media, dan Sosial Semiotik. Hasil penelitian ini menunjukan bahwa komika-komika ini memiliki persona unik yang berbeda-beda yang melekat pada diri mereka sehingga penonton mengenali ciri khas mereka.
\end{abstract}

Kata Kunci: Persona, Stand-Up Komedi, YouTube

\section{BACKGROUND}

Recently, Stand-up Comedy has become an industry that is gaining many interests, both from the comics and audiences. It indicates a context that allows the audiences to react, to participate, and to engage each other related to the jokes of the comics (Brodie, 2009). Many comics use Stand-up Comedy Competition Indonesia as a stepping stone to widen their career. With the unique and authentic persona, comics succeed to get many attention and support from the audiences and fans. People often watch Standup Comedy shows to boost their mood by laughing. Comics are usually known by the public by their persona and the way they deliver the jokes. There are several common techniques that are usually used by the comics, which are impersonation, rule of three, roasting, one-liner, simile, callback, observation and comparison (Destrianti, 2018). The jokes in Stand-up Comedy need to be delivered clearly by the comics to avoid misperception and to prevent offended audiences, and also the audiences need to get the jokes smartly.

Humor can be used as an effective persuasive tool to influence the target audience. Because of the existence of humor itself, it allows people to laugh or smile, making the mood more comfortable and refreshing. Humor can build a creative sense to overcome a situation (Hassan, 1995, p.17, as cited in Taufiq et al., 2018). Humor can also be considered a simulation because it can cause a laugh or smile response, whereas laughter is incited in response to humor. Stand-up comedy is defined as an encounter between a single performer who is standing and behaving comically and/or saying funny 
things to the audience without the use of props such as costumes, sets Mintz, 1985 as cited in (Afidah \& Wahyudi, 2014). The motives and role of stand-up comedy are interesting, ambiguous and to some point paradoxical. Comics often discuss topics such as ideology, politics, race, and other current events. Stand-up comics use certain performative methods to engage the audience and generate laughter due to the limitations of their properties. Furthermore, humor as a character reveals that a person's sense of humor is a personality trait. Every individual has a sense of humor, but it differs in intensity.

Since the early 18 th century, stand-up comedy has become a part of mainstream culture in Europe and America (Mintz, 1985, as cited in Afidah \& Wahyudi, 2014). Since a long time, comedy has become an important part of social culture, but in various forms, especially in Indonesia. In Indonesia, the comedy traditions of Ludruk and Ketoprak are examples. According to Van (1822) as cited in Lia (2014) journal, Ludruk is a dance with humorous stories performed by male comedians dressed as women. In Indonesia, stand-up comedy has only recently become a part of popular culture, despite the fact that the style has been around for many years. Through various media such as radio, television, newspapers, the internet, and so on, it has colored society. There is a section named "Humor" in Kompas and "Senggang" in Jawa Pos. While on television, there were comedy programs such as Lenong, Extravaganza, and Bajaj Bajuri.

In 2011, Kompas TV created a program named Stand-Up Comedy Indonesia, it is a competition for comedians where they tell jokes about certain topics while standing in front of many people. In the same year Metro TV also aired a similar program like Kompas TV which is named Stand-Up Comedy Show. Since then, this kind of program has attracted the interest of the society. With the tagline that they called 'Let's Make Laugh', Stand-Up Comedy Indonesia has various rounds in the competition which one of them is Guest Star
Roasting by this round the comedian participant must be make a series of jokes and tease a certain guest star it is presented to invite audiences laughter with no means of hurting the feeling of the guest star.

In the world of stand-up comedy, every comic will try to create the best setup in order to get the best punch line. Setup is basic information of telling the jokes and acts as a premise/introduction for the punchline. Setup needs to be short and true. Meanwhile, punch line itself is a funny part of the jokes where the comic expects the audience to laugh at, and functions as a closing for the setup (Carter, 2010 as cited in Thomas, 2013). To build a good setup for the best punch line, there are several techniques that the comic can use such as act out, call back, one liner, rule of three, hackler handling, self-bullying, and etc. All those techniques, however, will not reach its full potential unless the comic owns a specific persona. According to one of the most recognized stand-up comedians in Indonesia, Raditya Dika, persona is a "mask" that the comic wants to wear onstage. A good stand-up comedian is able to blend themselves into their persona, making their jokes even funnier. Moreover, the persona itself can be varying such as ethnic, family background, economic status, educational background, and many other aspects that can be considered as unique. In some cases, there are even comics who can even confuse the audiences because their chosen persona looks too real, that people started to think that their persona is the comic's real personality (Greengross and Miller, 2009 as cited in Naessens, 2018). It is possible because persona is developing from time to time, a new persona can be discovered along with the current development (Aarons \& Mierowsky, 2020). In Indonesia itself, there are 5 notable stand-up comedians with a unique persona namely Raditya Dika, Ernest Prakasa, Rizky Firdaus (Uus), Dodit Mulyanto, and Cak Lontong.

\section{Raditya Dika}

One of the most recognized and earliest stand-up comedians in Indonesia, Raditya Dika, chose the persona of being the 
expert of love and mainly targeting teenage audiences. In Raditya Dika's case, he chose the right persona because the target is specific and Radit is able to maintain the laugh from his audience every time he does stand-up comedy. Raditya Dika usually talks about his bitter past love story, his disagreement with the way teenagers nowadays engage in a relationship, and even routinely giving wise words for couples. All of that aspect could be found in his own stand-up comedy show entitled "Stand-up Comedy Raditya DIka" (SUCRD) in 2016 and 2017. What is amazing about Raditya Dika is that even after his marriage, he is still able to maintain his persona as the expert of love, but now shifted as a father and husband. The implementation of Raditya Dika evolving persona could be seen in his latest stand-up comedy show entitled "Cerita Cintaku" in 2019 and 2020.

\section{Ernest Prakasa}

Another stand-up comedian with a unique persona is Ernest Prakasa. Ernest took a persona based on his ethnic background which is a Chinese person. Using an ethnic background as a persona is also a good choice as it can trigger people to consider and examine the current racial systems or experiences, promote social reciprocal or cultivate collective identities, and contributes to strengthen existing sociocultural norms and stereotypes, and authorize racial social experiences (Green, 2012). Ernest did exactly those theories in his stand-up comedy as he talks about racism, stereotype, false paradigm, bad experience, and norms infringement that have ever happened to him as a Chinese person that lived in Indonesia.

\section{Rizky Firdaus}

Rizky Firdaus Wijaksana or mostly known as Uus, is an Indonesian comic that became more famous after participating in Stand Up Comedy Indonesia season 3 (SUCI 3) competition. As a comic, Uus delivers his jokes by using act out type, which is delivering the jokes with eccentric movements to convey the punch line of the jokes. He often shows funny facial expressions to complete his jokes and make people laugh in sudden just by seeing his face.
He also likes to talk in a high voice, like suddenly shouting as the punch line of the jokes and sometimes mixed with bad words.

\section{Dodit Mulyanto}

Another comic that became famous by participating in Stand Up Comedy Indonesia is Dodit Mulyanto. In most of his performance, he brings a violin and it becomes his persona. Other than that, he also likes to point at someone while delivering his jokes by saying "kamu, iya kamu". He is applying a flat type of jokes, which is delivering his jokes with a flat and no expression face. During telling the jokes, Dodit always maintains his face expression and restrains himself from laughing. The way he tells the jokes is in a soft way and usually he relates the jokes with his personal life as a Javanesse.

\section{Cak Lontong}

Cak Lontong is known as a stand-up comedian who also occupies Indonesia's TV shows. His clever jokes have made many people know his name. $\mathrm{He}$ is great at anecdotes, syllogisms and puns as well. Not infrequently, by using material from basic premises that can be from words or phrases, some of which use the words 'patient', 'think', 'fear', and 'clueless' in his stand-up comedy material, he also makes new proverbs and likes to make a twist on his jokes. Therefore, the persona of each individual mentioned above will be the focus of the discussion.

\section{Humor}

In literature humor is describe with its various aspects. Dieter (2000) as cited from (Özdemir, 2017) states that the most forms of humor are based on incongruity. To look at it another way, humor is often created from unexpected reactions to familiar situations which defy social norms. Humor can be hard to achieve it is because of different people may interpret it differently. Therefore, if an audience is unaware of the familiar part of the joke, the unexpected part or punch line will be missed. According to Dingfelder (2006) quoted in Özdemir journal, the enjoyment of humor often comes from seeing familiar situations with new eyes (Özdemir, 2017). 
Within juxtaposition of familiar and unfamiliar, humor provides fresh insight into a familiar situation.

Humor, which can be described as the presence of humorous effects such as laughter or pleasant feelings, plays an important role in our lives. The main role of humor is to release thoughts, sentiments, or feelings, which has a positive effect on human health. In a social situation, humor's cathartic properties cause most people, regardless of their beliefs, social position, or cultural differences, to react to a humorous stimulus. Furthermore, humor may provide important details about linguistic, psychological, neurological, and sociological phenomena. There are many types of humor, which are wordplay, irony and sarcasm, but there are also few formal taxonomies of humor characteristics, it is almost impossible to produce a general algorithm that can identify all of the various forms of humor, and even humans can't classify them all perfectly. The message's humorous content can have a persuasive impact, increase message linking, and create a positive mood. Humor is widely present in every culture. There is no culture in today world that doesn't possess a sense of humor. It is found everywhere-in movie industry, television, in books and newspapers, in our conversations, and in graffiti (Berger, 1987) as cited from (Djambaska et al., 2015).

In this modern era, personal branding is one of the most important elements for anyone. By having strong personal branding, the society will be remembering someone through his uniqueness. Personal branding is specifically intended to get profit and brand image that is associated with a particular entity or person. According to Lair in Hitching's analysis, maintaining personal branding is important, regardless of age, because anyone can be seen as important and valuable commodity in the marketplace (Hitchings, 2014). There is no employer affiliation with personal branding; rather, an individual is promoting himself instead of a company- related brand.

According to the experts in Zarkada's analysis, personal branding is understanding what makes someone uniquely special, as well as differentiating oneself by releasing your inner genius and relating it to your passion. It also entails providing something of value to viewers in a way that elicits an emotional response from them. Individuals participate in a range of practices to make themselves known in the marketplace, typically with the aim of achieving gainful jobs (Zarkada, 2012). An individual need to create new marketing concept that refers to the individual's marketing strategy to promote the individual's unique personal characteristic.

Personal branding is mostly implemented by celebrities, artists, politicians, comics, influencers and others. Public figures that often appear on the media definitely want to have good and unique image in front of the public audiences, so that they maintain their careers in the media. In order to get the public's attention, they have to build, develop, maintain and promote their own personal branding also maintain it so they will not easily disappear from the media. For example, Nissa Sabyan, who is a hot topic for the media recently because she was cheating with her teammate. Before this case blew up, Nissa Sabyan is well-known as religious woman with great voice and sings religious songs, which is her personal branding. She built a very good image of her and people's opinion towards her is a good girl. But then she is having affairs with her teammate, Ayus. Because of this case, Nissa's image becomes bad in front of the public. The public started to blaspheme Nissa and Ayus, who is actually has married. And now, Nissa isn't known as a religious and good girl anymore, but a cheater and the cause of Ayus and his wife divorced.

\section{Personal Branding Phases}

1. According to Tariq Khan (Tariq Khan, 2014), personal branding is involving three phases, which are: Establish a brand identity. Individuals need to be distinct to make them stand out in a crowd and fulfill the needs of a particular target market. Individuals have to find out their uniqueness that can stay in public's mind. 
2. Develop the brand's positioning. This phase can be done by managing actions, communication, and symbolism to establish an active communication of one's personal branding.

3. Evaluate a brand's image. This to fulfill the personal and professional goals and by doing that, personal branding can help in competing others in marketplace. Individuals who participate in continuous learning grow their human resources, boost their social capital through exposure and notoriety, and gain access to financial success and economic profitability.

In the world of stand-up comedy, comics are not only demanded to possess knowledge of the technique to do a stand-up comedy. In fact, they also need to master the Comic Stage Persona (CSP). Mastering CSP is probably a must, if any comic wants to be successful in their show. According to Aarons \& Mierowsky (2020), CSP allows comic to make a jokes with their corresponding persona. CSP also create awareness about what jokes should be told by them, and what is not. It is important because different persona brings different result to the punch line. For example, Rigen Rakelna who is widely known as a temper comedian will not be able to pull a successful show if he uses a material similar to Fico Fachriza, because Fico usually tell jokes in a slow and soft tone. Regularly use persona in the show, can also make the persona itself stick to the comic and becomes their uniqueness. Still based on Aarons \& Mierowsky (2020), CSP enable woman to standup and tell the jokes, based on their experience as a woman.

Furthermore, according to Naessens (2018), CSP is a combination between learning process, communication, and any types of expression, that is takes part in the stand-up comedy. Not only have that, CSP also incriminated several aspects such. Moreover, Naessens (2018) then explained, that CSP is adaptive. It means that, persona is keep changing and developing from times to times. It offers flexibility to the comic that makes them still attractive even though the trend or the generation has been shifted. By implementing CSP to the material, the quality of the comic's show will increase exponentially because of the growth from the audience engagement factor. Because the CSP is keep evolving, there are demands for comics to adapt and formulate new material based on the recent trend.

As Aarons \& Mierowsky (2020) and Naessens (2018) both agreed that persona (CSP) in stand-up comedy are heavily related to the personality and identity, it is supported by (Rutter, 2001 as cited from Dore, 2018) which explained that the initial purpose of personal "brand" can also be implemented in the world of stand-up comedy, as a construction of comic's identity through the use of persona.

\section{METHOD}

This research would analyze the use of persona in construction of identity for standup comedians. The sources for our research will be mainly from Stand Up Kompas TV YouTube channel, therefore the data will be in a form of video. The first reason we select Kompas TV YouTube channel is because it is the biggest Stand-up Comedy channel in Indonesia and all 5 comics that we select had featured at least once in Stand Up Kompas TV YouTube channel. The other reason we decided to collect the data from only one source is to prevent bias in analyzing the comment, because different channels might have different audiences with different backgrounds. Based on that data, we would organize 3 steps in this research:

The first step, we will analyze the comic's performances in the video on how the comics deliver their jokes, because comics always learn their audience so they can deliver the message on their jokes perfectly to the audience. Some of comic's use their cultural identity to deliver the jokes and some of them also use their past as their jokes. Every comic must have their own characteristics to survive in the comedian stage so they can get more famous.

The second step, we will analyze the comic's characteristic to the elements of identity and see what element that they have. 
The elements of identity consist of cultural identity, which related to a group's tradition, language, habits, etc. and there is also social identity, which related with gender, social levels, age, jobs, etc. and the third is personal identity which related to gesture, voice, body parts, and the comics' appearances.

The last step is this research would implement the encoding-decoding concept. The concept is selected mainly because of its functionality to understand that different audiences (receivers) might differently interpret the message from the producer (sender). This step will be done in order to understand whether persona has successfully contributed to the construction of the identity of a comic or not.

\section{RESULT AND DISCUSSION}

In order to fully understand, whether or not the comics has successfully construct their identity through persona, we will need to understand how the comics blend the persona into their material/jokes, did the audiences understand what the comics are trying to do, and how Stand Up Comedy Kompas TV YouTube channel perceives the comics.

We considered those 3 aspects above because stand-up comedy is a two way communication, in which the comics deliver the jokes and the audience's response with laughter. Then, the Stand-up Comedy Kompas YouTube channel is selected mainly because the video of the comics was uploaded there. Thus, it would be interesting to see how Kompas TV perceived their comics. Moreover, it will also provide us with the additional perspective, other than the audiences, to determine whether the comics have successfully blended with their persona or not. With that being said, it shows how the 3 aspects were heavily related to each other. To do that, we will select one video with the most views from each comic that was uploaded in Stand-Up Comedy Kompas TV YouTube channel. Therefore, all of the discussion below will only use the videos from this source:

The identity construction displayed by Comics is intended so that they have distinctive features that help them to be easily remembered by the audience and have an interest and can help them in choosing material that is similar to their identity. Nowadays, we can search for many videos from any year on YouTube. It also applies to stand-up comedy. Kompas TV conducts a TV Show which is Stand-up Comedy Indonesia (SUCI) since years ago and uploads the videos of each comic on Kompas TV's YouTube channel. Each YouTube video must have a picture as its thumbnails because in the creation of meaning, pictures have the same value and influence as written texts (Perdana, 2020).

The editor usually creates click-bait thumbnails to attract more audiences to watch the videos. From the thumbnails of the comics that are uploaded on Kompas TV's YouTube channel, we can see the relation between the thumbnails and the comics' identity and persona as explained below. Other than presented material from the comics and Stand-Up Comedy Kompas TV channel, the construction of identity for the comics is by identifying the audience responses.

Audience responses are considerably the most important aspects in stand-up comedy, because the main purpose of comics telling their jokes, is to hear the audience responses, whether the jokes are funny or not. There are 3 audiences' responses that we will use. Firstly, if the audiences are laughing, it means the jokes are funny. Secondly, if the audiences are clapping, it means the jokes left a deep impression on them, probably due to their persona. Lastly, if the audiences were quiet after hearing the punch line, it means that the jokes are not funny or the audiences do not catch what the comic wants to deliver.

1. Raditya Dika

Construction of Identity through the Presented Material

As is seen in the video from KompasTV YouTube Channel entitled GRAND FINAL Stand-Up Comedy Raditya Dika: (JADUL) Gua Baru Aja Putus Cinta SUCI 1, researchers can make an analysis about Raditya Dika. Raditya Dika's identity as a love expert made him very well known 
about love relationships and also conveyed material about romantic relationships, in delivering material Radit often made the audience amused by his love experience which the audience also seemed to have experienced. He is able to convey his jokes precisely which makes the audience feel the same experience. Raditya brand himself with a unique characteristic, Raditya participates in a range of practices to make him known in the marketplace, typically with the aim of achieving gainful jobs (Zarkada, 2012). It can be concluded that Radit shows his identity as a love expert as it can be seen from his presented material; he is presented about his experience about love.

\section{Construction of Identity through the} Stand-up Comedy Kompas TV Thumbnail

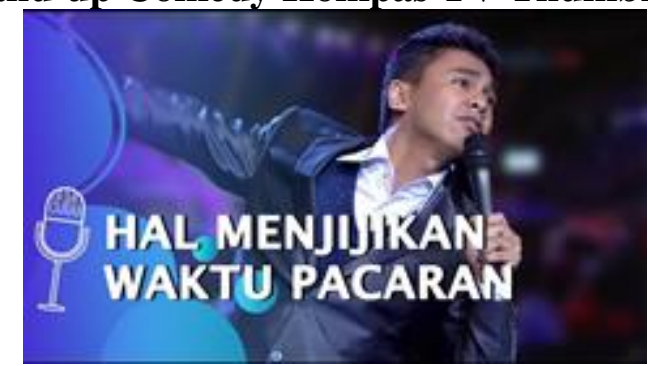

Picture 1. Raditya Dika Video humbnail

With the persona that Raditya Dika has,which is a love expert, Radit has succeeded to attract the publics' attention. In most of his Stand-up Comedy performances, Stand-Up Comedy Kompas TV YouTube channel always puts some words on the thumbnail. For example, it is "HAL MENJIJIKAN WAKTU PACARAN". By seeing the thumbnails of Raditya's videos, audiences can assume that Raditya is a comic that is identical with love and relationship. In conclusion, Radit is identical with love problems of young people and it can be seen through his stand-up comedy videos' thumbnails that mostly put words related to relationships.

\section{Audience Responses towards Material that the Comics Brought}

If we look at the video of Raditya Dika, we can see that in the first minute of his performance, the audiences rarely laugh, even if they laugh, they don't laugh hard at the jokes. This is mainly because the audiences are not really aware of who Raditya Dika is, and what kind of persona that he possessed. However, after the 1 minute mark is passed, the audience realizes Radit has many experiences in love life that the audience also experienced. Thus, they are curious of what other experiences that Radit has encountered (Dingfelder, 2006 as cited from Özdemir, 2017). It is proven in 1:38 until 1:53 mark, when Radit told a situation that most of the audiences had been into, they found it funny and began to laugh really hard at the jokes. Raditya Dika also gets a round of applause at 4:50 until 5:00 mark, when he tells jokes about "Where is my love". It seems that most audiences can relate into what Radit has said, and as a sign of approval they began to clap. But Radit also experienced a silent moment in that show in the 5:10 until 5:25 mark. It seems that this time Radit fails to deliver a material that the audience can relate to, despite almost all of them are already much aware of Radit's persona. As a result, we can hear that audiences were silenced for about 15 seconds whereas they should laugh. Thus, correlation of material (jokes) with the audience is a very important aspect that every comedian should note. As can be seen, there is a possibility for even a pro like Raditya Dika to make such a mistake.

In conclusion, Raditya Dika with the help of his stand-up comedy experience, able to play with the timing and successfully expressed his persona as the expert of love. Proven by his love experience that is told in a different way, but the audiences can still relate and enjoy the jokes. As can be seen, the audiences laugh over and over again.

\section{Ernest Prakasa}

\section{Construction of Identity through the Presented Material}

According to Dingfelder (2006), humor becomes more enjoyable when people experience familiar context with new perspectives (Özdemir, 2017). Ernest Prakasa, who is a Chinese descent, made himself use it as material in his jokes, conveying material based on his experience as a Chinese in Indonesia, making the audience laugh at what happened to him. The audience also felt it when they saw Chinese people in the 
settlements, how they saw Chinese people and how they treated Chinese people.

In conclusion, Ernest is able to show his Chindo (Chinese Indonesia) identity because of his presented material he talks about his experiences being a Chindo.

\section{Audience Responses towards Material that the Comics Brought}

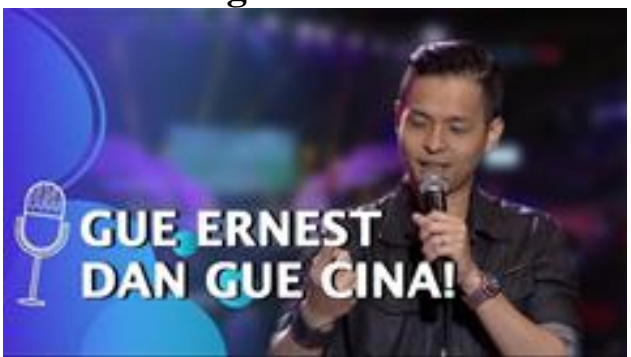

Picture 2. Ernest Prakasa Video Thumbnail

Different from Raditya DIka, Ernest

Prakasa is well-known as Chinese-Indonesian comic. He mostly talks about his life as a Chinese-Indonesian and how people treat him. Looking at the thumbnails of his videos, mostly, the editor puts a sentence that is related to the presented material. For example, on the picture above, there is taken from his Stand-Up show called "GUE ERNEST DAN GUE CINA" sentence on the thumbnail. Some other videos of Ernest also has related sentence on the thumbnails, such as "BUKU PELAJARAN DI SEKOLAH, DISKRIMINASI" when Ernest talked about how he was discriminated in school because he is a Chinese-Indonesian. In other words, Ernest is known as a Chinese-Indonesian comic that often presents materials related to how Indonesian treat Chinese-Indonesian. It can be concluded that the persona of Ernest is his mixed races, Indonesian - Chinese. He succeeded to build his personal branding as a Chinese Indonesian comic with the jokes of his life as Chinese Indonesian.

\section{Audience Responses towards Material that the Comics Brought}

Moreover, Ernest Prakasa in his performance did something a little different to what Raditya Dika did. Instead of letting the audience guess what is his persona which also related to his jokes, Ernest prefers to tell the audience right away, as it is shown in 0:04 until 0:08 mark, where he said "My name is Ernest and I am Chinese". Audience absorbs this information as a clue that in his further performance Ernest will mainly tell the jokes about his experience as a Chinese person (Aarons \& Mierowsky, 2020). It proved to be a great decision because one of his jokes about "Martabak" and "Taichi" in the 1:46 until 1:56 mark, makes the audience laugh really hard. As it is widely recognized, "Martabak" and "Taichi" are heavily related to the Chinese person. Thus, Ernest did a really good job finding a link between him as a Chinese person, with "Martabak" and "Taichi". Audiences also showed a response of agreement by clapping their hands in 1:17 until 1:22 mark when Ernest talked about Chinese traditional medicine, and in 1:59 until 2:03 mark when Ernest talked about the ingredients of "Martabak". On the other hand, Ernest also did receive a silent moment at 2:23 until 2:32 mark, when he talked about apartments and rich people. It seems that the audience does not experience or are not able to catch what Ernest is trying to deliver, as it also does not have any connection with him being a Chinese person. Again, Ernest's case emphasizes the importance of making material (jokes) that the audiences can relate to. It can be concluded that Ernest Prakasa from the earliest stage of his performance has successfully established his persona as a Chinese person with different experience living in Indonesia. It is proven by the audience's laugh whenever Ernest tell his experience and Chinese stereotypes in Indonesia.

\section{Dodit Mulyanto}

\section{Construction of Identity through the} Presented Material

Dodit Mulyanto with his innocence and the use of standard language by carrying the violin became an identity that was very memorable in the minds of the audience, his comedy material which discussed how his life in a village was different from his friends, which made him look like a respected person in his village. Dodit, who often shows his innocent face with a comedy without expression, makes him even funnier. Dodit makes himself distinctive so he can stand out among other comics and to fulfill the needs of 
a particular target market (Tariq Khan, 2014). We can conclude that Dodit constructed his identity as a not expressive comic because we can see how he delivers his material without any expression.

\section{Audience Responses towards Material that} the Comics Brought

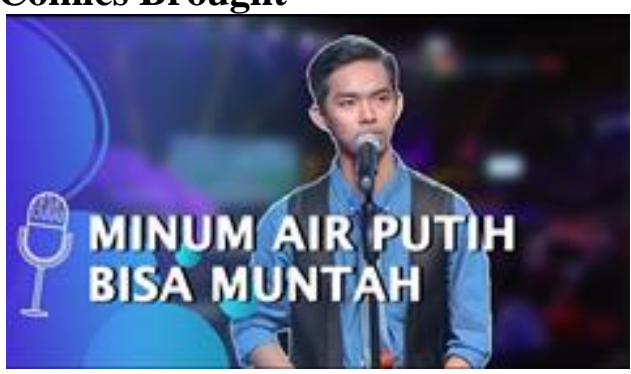

Picture 3. Dodit Mulyanto Video Thumbnail

Dodit mostly delivers his jokes in a flat way. As we can see in the video entitled [FULL] Stand-Up Comedy Dodit: PECAH! Saya Jawa, tapi Megang Erat Budaya Eropa SUCI 4, he has flat facial expression.

$\mathrm{He}$ always maintains his noexpression face during the performance. In most of the videos of him, the thumbnail is showing his flat-face with neat iconic appearance. Some videos also put the thumbnails that show Dodit with his violin, as known, Dodit's violin is one of his identities as a comic. He brings his violin in every performance.

Concluding this part, we can conclude that his persona is how he maintains his noexpression face during presenting the material. He also brings his violin in most of his performances and like to point at the audiences. As seen on most of his stand-up comedy videos' thumbnail, it shows his face with no expression.

\section{Audience Responses towards Material that the Comics Brought}

Meanwhile, Dodit Mulyanto had a slight advantage in telling the audience what his persona is. Before Dodit opens his performance, there is an opening video which enables Dodit to show his persona as a tacky village person to the audience, so the audience is more aware of who Dodit is and understands the scope of his jokes (Rutter, 2001 as cited from Dore, 2018a). It is proven to be significantly effective because the audiences start laughing right away the moment Dodit talks his opening sentence at the 1:30 mark. Even more amazing, Dodit got a significant amount of laughs and clapped in 2:44 until the 2:54 mark when he said "I vomit when I drink water". It is mainly due to the fact that audiences are well-aware that Dodit is a tacky village person, and when he said "I vomit when I drink water" it truly represents Dodit's persona. Dodit's punchline using his persona was also absolutely on point, there is only once that his punchline missed, which is in the 3:19 until 3:23 mark, proven by the audiences that stay quiet in that moment. It can be said that Dodit has probably a strong persona that makes his jokes catch on easily with the audiences. Even when his punchline missed once, it's not a problem for Dodit to recover and successfully deliver his next jokes. In summary, Dodit Mulyanto has successfully established his persona of a tacky village person, even before he enters the stage, thanks to the help of the opening video. Because of that, a barrage of laughter comes whenever words or sentences that Dodit said.

\section{Cak Lontong}

\section{Construction of Identity through the Presented Material}

According to Aarons \& Mierowsky (2020), CSP allows comics to make jokes with their corresponding persona. Cak Lontong's strict character with his comedy which is sometimes complicated or difficult to understand makes the audience laugh confused, explaining his joke with a flat face adds to the confusion of the audience, this makes the audience need a few seconds to understand his joke. At the end of each explanation of his jokes, he often uses the word "Mikir" which aims to make the audience better understand his jokes, which can be said to be too complicated. In conclusion, Cak Lontong shows his identity as a comedian that make his audiences think before he continues his jokes; it is because in the middle of delivering the material he always said "Mikir". 


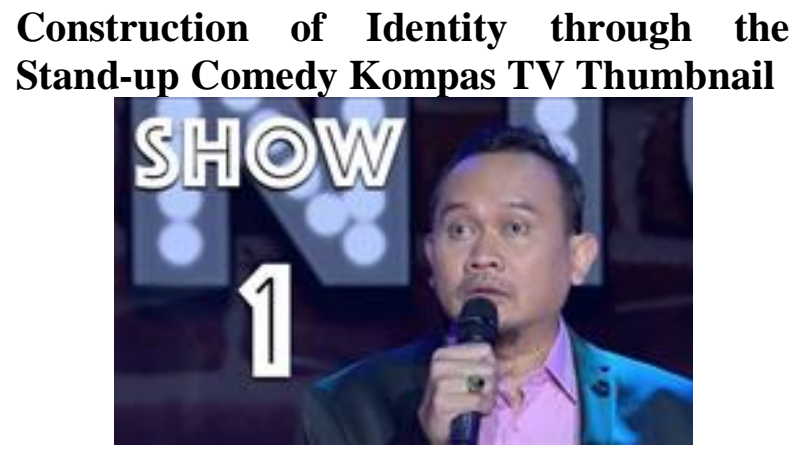

Picture 4. Cak Lontong Video Thumbnail

Cak Lontong is well-known for his clever and plot-twist jokes. Similar to Dodit, Cak Lontong also always performs with a noexpression face. He tries to keep his face straight during delivering the jokes. By looking at the photo in the thumbnail, we can see the identity of Cak Lontong through his iconic face. The naive face that he always shows has his own characteristic that is very familiar to the audiences.

We can conclude that Cak Lontong's persona is his out of the box jokes and also the way he put straight face during presenting the materials. It can be seen also through the thumbnails of Cak Lontong's videos that show the iconic straight face of him.

\section{Audience Responses towards Material that the Comics Brought}

On the other hand, Cak Lontong did a similar set-up to Raditya Dika, which requires the audiences to guess what Cak Lontong's persona is. Luckily, Cak Lontong is famous enough that some people already knew his persona from his previous performance, so it helps to understand his jokes a little bit better. As can be seen in 1:49 until 1:53 mark, Cak Lontong failed to gain the audience's laugh because they did not understand what the joke meant, and just realized what it meant 2 or 3 seconds later after the jokes had been told. As the audiences observe and get what Cak Lontong's persona is, they immediately laugh at the next joke at 1:57 until 2:03 mark. So, a persona that is not shown-up immediately like Cak Lontong (Raz, 2012), usually requires some time for the audience to understand in order to fully catch the next jokes and enjoy it to the fullest.

As can be seen, Cak Lontong seems to struggle to tell the audience what his persona is. As a result, there is not much laughter in the beginning of his stand-up. The audience seems too late to realize that Cak Lontong's persona is the plot-twist and his iconic flat face, proven by the laughter that just comes in the middle of his performance.

\section{Uus (Rizky Firdaus)}

\section{Construction of Identity through the Presented Material}

Using persona in the show can also make the persona itself stick to the comics and become their uniqueness (Aarons \& Mierowsky, 2020). Uus or Rizky Firdaus, whose performance often features a silly face, helps him in delivering his jokes material, his silly face is very helpful in delivering jokes, but the audience doesn't laugh too much because the material he delivers is not mature. The material he chose was more of roasting where some of the audience became confused and did not understand the jokes. To conclude, the identity that Uus wants to make is his silly face because in delivering his material he always uses his face expression.

\section{Construction of Identity through the} Stand-up Comedy Kompas TV Thumbnail

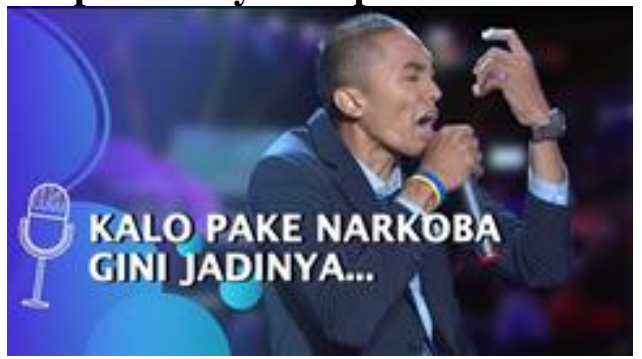

Picture 5. Uus Video Thumbnail

Uus is well-known as a comic that always acts out while presenting the materials. Most of the thumbnails of his videos in YouTube are showing the silly face expression that he did during his performances. The example is in the picture above. He doesn't care about how silly his face is and it's his uniqueness. The funny face expression of Uus becomes his persona that everyone is waiting for when they watch him doing Stand-Up comedy and success making people laugh.

After researching about Uus, the persona that Uus has is the way he shows funny face expression every time performing stand-up comedy. He also is identical with his 
bald head. It all can be seen on the thumbnails of his stand-up comedy videos that show his funny face expression.

\section{Audience Responses towards Material that the Comics Brought}

Last but not least, there is Uus (Rizky Firdaus) who performs his first and last standup comedy in SUCI competition, as it is written in the title of the video. Uus badly failed in the show mainly because he did not effectively utilize the opening video segment, in which Dodit perfectly used. Not only that, Uus also shows the inconsistency of using his persona, proven by Raditya Dika's comment which said Uus is "half-mature" as a stand-up comedian. Uus opened his show by using a "mismatch of words" persona, where he said his long name is "Uus mi apah?", which refers to the famous slang in Indonesia "Cius mi apah?". It gained a positive response by the audience because almost all of them were laughing so hard. This is actually a solid start to strengthen his further jokes. However, he messed up by roasting his fellow comics namely Ge Pamungkas and Kemal Palevi in 1:13 until 1:34 mark. As we can see, roasting is clearly not the best persona for Uus to use, and it is proven by almost no audience laugh from 1:13 until 1:34 mark. In summary, it is important to bring only one persona to the stage, as bringing more than one persona could confuse the audience, resulting in them thinking about the jokes rather than laughing at the jokes (Aarons \& Mierowsky, 2020).

It can be concluded that Uus actually has prevailed in telling the audience what his persona is, which the "mismatch of words" is. However, he started losing the laugh from the audience because he tried to do another type of persona, in which he doesn't fully control. Because of that, it is important to only bring 1 persona to the stage, as audiences can't identify all types of jokes perfectly at the same times (Raz, 2012).

\section{CONCLUSION}

In summary, there are at least three fundamental points that can be taken from this study:
Firsty, it is proved that creating a stand-up comedy material from the comic's past experience could be very effective since the success ratio from our data is quite high. Raditya Dika, Ernest Prakasa, and Dodit Mulyanto are the comics that rely heavily on their past experience in order to produce a great material that can results in a big and simultaneous laughter. On the other hand, Cak Lontong who depends on the effectiveness of the words used, and Uus who depends on his funny silly face, makes audience needs some times to settle with their persona, resulting in less laughter especially in the beginning part.

Secondly, because all of the videos were taken from Stand Up Comedy Kompas TV, we can assumed that Kompas TV knew exactly the persona of their own comics, and tried to put a combination between image and words in which shown each comic's persona. Kompas TV purposes for doing such combination, is to give audience a clear background to the YouTube's viewers before they began watching. Thus, the moment they start watching, they do not need to learn what is the comic's persona and can immediately enjoy the performance.

Lastly, we can state that the laughter from the audience can be an accurate measurement to evaluate whether the audience can understand the comic's persona or not. In our data, big and continuous laugh can be found in Raditya Dika, Ernest Prakasa, and Dodit Mulyanto performance. It means that the audience can understand each comic's persona and therefore, are able to enjoy the material that they brought. Meanwhile, small and off laughter are found in Cak Lontong and Uus performance. Based on our results, there are two possibilities why it can happen. First possibility is the audience needs some times to understand comic's persona like in, Cak Lontong case. Other possibility is that there is inconsistency in the use of persona, like in Uus case.

\section{REFERENCES}

Afidah, L., \& Wahyudi, R. (2014). How It Starts and Ends: a Study of 
Indonesian Stand-Up Comedy. Jurnal Pendidikan Bahasa Dan Sastra, $\quad 14(2), \quad 170$. https://doi.org/10.17509/bs_jpbsp.v1 $\underline{4 \mathrm{i} 2.716}$

Brodie, I. (2009). Stand-up Comedy as a Genre of Intimacy. Ethnologies, $30(2)$, 153-180. https://doi.org/10.7202/019950ar

Debra Aarons \& Marc Mierowsky (2020): The Marvelous Mrs. Maisel as an alternative history of stand-up, Comedy Studies.

Destrianti, E. (2018). Journal of English Education and Teaching (JEET) Vol.2.No.3.2018 1. 2(3), 1-6.

Dore, M. (2021). HUMOUR IN AUDIOVISUAL TRANSLATION : theories and applications. S.L.: Routledge.

Gil Greengross and Geoffrey F. Miller, "The Big Five Personality Traits of Professional Comedians Compared to Amateur Comedians, Comedy Writers, and College Students," Personality and Individual Differences47, no. 2 (2009): 79.

Green, A. L. (2012). The Impact of Comedy on Racial and Ethnic Discourse (Doctoral dissertation, University of Cincinnati).

Irena, L., \& Rusadi, U. (2019). The Commodification of Chinese Stereotypes in Humour of Stand up Comedy Indonesia. International Journal of Multicultural and Multireligious Understanding, 6(2), 376.

https://doi.org/10.18415/ijmmu.v6i2. 714

Multicultural and Multireligious Understanding, $\quad 6(2), \quad 376$. https://doi.org/10.18415/ijmmu.v6i2. 714

Naessens, E. D. (2018). The development of Comic Stage Persona (CSP) in standup comedy: An interdisciplinary approach to an intersubjective performance phenomenon. http://hdl.handle.net/2262/83328
Özdemir, E. (2017). Humor in elementary science: development and evaluation of comic strips about sound. International Electronic Journal of Elementary Education, 9(4), 837850.

Perdana, A. S. D. (2020). A Critical Social Semiotics Approach on Text-Image Relationship: Revisiting Bali Nine Ringleaders.

Tariq Khan, M. (2014). The Concept of MarketingMix' and its Elements. International Journal of Information, Business and Management, 6(2), 95120.

Taufiq, A. M., Anshari, A., \& Ramly, R. (2018). A Study of Humor in Bone Regency: A Socio-pragmatic Review. Journal of Language Teaching and Research, 9(1), 141. https://doi.org/10.17507/jltr.0901.18 